\title{
SOCIO-SEXUAL COMMUNICATION: A REVIEW OF THE SENSORY MODALITIES USED BY NON-HUMAN PRIMATES
}

\author{
Laís Alves Antonio Moreira ${ }^{1,2 *}$, Daniel Marques Almeida Pessoa ${ }^{2} \&$ Maria Bernardete Cordeiro de Sousa $^{1}$ \\ ${ }^{1}$ Universidade Federal do Rio Grande do Norte (UFRN), Centro de Biociências, Departamento e Fisiologia, Laboratório de Endocrinologia \\ Comportamental, Campus Univesitário Lagoa Nova, Natal, RN, Brazil.CEP: 59072-970. \\ ${ }^{2}$ Universidade Federal do Rio Grande do Norte (UFRN), Centro de Biociências, Departamento e Fisiologia, Laboratório de Ecologia \\ Sensorial, Campus Univesitário Lagoa Nova, Natal, RN, Brazil.CEP: 59072-970. \\ E-mail: laisantoniomoreira@gmail.com, pessoadma@cb.ufrn.br, mdesousa@cb.ufrn.br
}

\begin{abstract}
As social animals, primates use signals to transmit information about social and sexual status to conspecifics. When these signals lead receivers to change their behavior, we can consider that communication between the individuals has occurred. Primates can produce and use four sensory modalities to communicate between conspecifics: acoustic, chemical, visual and tactile. The use of each modality depends on the social and physical environment, the receiver's sensory system and the context. In this review, the authors present behavioural evidence of each sensory modality used in socio-sexual contexts and compare this evidence for Old World and New World monkeys in an attempt to guide future studies on the evolution of communication. Keywords: Primate communication; sensory modalities; socio-sexual signals; Old World monkeys; New World monkeys.
\end{abstract}

\section{INTRODUCTION}

Communication is generally defined as the interaction between at least two individuals, a sender and a receiver, with the transmission of information and its subsequent use to change the receiver's behavior (Bradbury \& Vehrencamp 2011). It can be considered in terms of three components: signal production (the type of signals), usage (producing signals in an appropriate context) and comprehension (responding appropriately to other signals) (Seyfarth \& Cheney 2010).

Most primates, as social animals, need to communicate with conspecifics and individuals of other species in different contexts, such as: agonistic interactions, territorial defense, mating rituals, foraging and group cohesion. Primate communication has been the object of studies for a long time and the meaning of the signals is still being unraveled (Hauser et al.2002, Zuberbuhler 2000a, 200b, Di Bitetti 2005, Slocombe \& Zuberbuhler 2005 a, b, Arnold \& Zuberbuhler 2006a, 2006b, Heymann 2010).

Among the major modalities of communication used by vertebrates (acoustic, visual, chemical, tactile, electrical), primates can produce and receive signals from four of these: acoustic, chemical, visual and tactile (Maryanski 1997). Acoustic communication involves sound production consisting of vibrations that propagate in a medium over short and long distances, but can be modified by boundaries such as the ground, forest canopy or surface of the water (Bradbury \& Vehrencamp 2011). Sound undergoes spreading loss as it propagates rapidly away from the sender, characterizing its low persistence, but providing directionality to the signal (Bradbury \& Vehrencamp 1998). Chemical signals used for communication between conspecifics are usually called pheromones, organic compounds that differ in size, shape and composition (Snowdon et al. 2006) Primates disseminate chemical signals by rubbing sebaceous glands onto a surface, object or food, in addition to depositing urine and feces with secretions from sex accessory glands or the anal gland (Kleiman 1966). Their transmission is mainly via diffusion, with high persistence, low directional information and low propagation speed (Bradbury \& Vehrencamp 2011). Primates use reflected light from the sun to produce visual signals. These signals can be characterized by brightness or intensity, spectral composition or color, spatial characteristics (size, shape, surface features and color pattern of color patches) and temporal variability in intensity, color and spatial properties (Dusenbery 1992). Since visible light travels in straight lines, visual communication between two animals must 
be direct, without large or opaque objects situated directly between them, making it highly directional (Dusenbery 1992). Ultimately, tactile signals are highly directional and immediately perceived, given the direct contact between individuals, especially conspecifics, and their variable persistence (McGregor 2008).

Context plays an important role in communication and receivers may integrate the information received in the context (Tomasello \& Carpenter 2007). Recipients may even take the nature of previous interactions into account when perceiving the meaning of signals, such as the relative rank of the signaler and recipient (Cartmill \& Maestripieri 2012, Roberts et al. 2012). Social and sexual contexts demand interaction between individuals and the exchange of information about the animal's quality, rank status and sexual availability.

Animal communication, like any other behavior, can be studied from four different perspectives: mechanistic, ontogenetic, functional and phylogenetic (Tinbergen 1963). Accordingly, this review presents functional perspectives by indicating some behavioral data for all four sensory modalities exploited by primates in socio-sexual contexts. Our aim was not to review all studies on the four modalities, but rather to review the core modalities of communications used by primates. Furthermore, we compare evidence for Old World monkeys (Catarrhini) and New World monkeys (Platyrrhini) as a means of understanding the evolution of primate communication.

\section{ACOUSTIC COMMUNICATION}

The emission of acoustic signals is an important communication modality for most primates. The wide use of acoustic signals is related to social and physical environments, and as primates are usually arboreal, it is more difficult to see conspecifics (Fedurek \& Slocombe 2011). Furthermore, as members of a group can sometimes be separated as they travel and forage over large distances, acoustic signals can disseminate long distances and deviate from obstacles, making them useful for primate communication (Fedurek \& Slocombe 2011).

Unlike human oral language, which is formed by different phonemes and semantic structures, nonhuman animal acoustic communication is simpler (Fedurek \& Slocombe 2011), albeit sufficient to transmit messages about predators, food sources, conspecific reproductive state and social condition.

In socio-reproductive contexts, primates can produce acoustic signals. Several nonhuman primate females can produce loud and distinct sounds immediately before, during and/or after copulation, although the causes that explain this behavior are not well known (Maestripieri \& Roney 2005, Pradhan et al. 2006). Pfefferle et al. (2008a) sought to explain the function and information contained in calls produced by Barbary macaque females (Macaca sylvanus) during coupling. The authors tested two hypotheses: first, calls are produced to indicate the female fertile period; second, these calls might influence male ejaculation. Correlations between acoustic analyses of calls and hormone measures were undertaken and a temporal association was made between coupling and call emission. The authors found that calls produced by females during coupling influence male ejaculation, but do not signal their fertile period. In another study using playbacks, Pfefferle et al. (2008b) recorded female calls produced during coupling with and without ejaculation. Males exposed to playbacks of females calls during coupling with ejaculation gazed longer at other females and approached them at a higher frequency when compared to exposure to playbacks of female calls during coupling without ejaculation. The authors hypothesize that female calls might be signals to their partner, enhancing the probability of ejaculation and fertilization, and to other males of the group to announce successful couplings, thereby increasing interest in future coupling. Thus, the emission of calls during coupling might induce spermatic competition.

In 2011, Engelhardt et al. showed for the first time for primates that females of long-tailed macaques (Macaca fascicularis) signal if they are paired or not, by the structure and frequency of their calls during coupling. Moreover, these vocalizations can signal coupling accessibility and the social hierarchy of their partners. This study, together with others using nonhuman primates [Cercocebus torquatus atys and Macaca nemestrina (Gouzoules et al. 1998), Papio cynocephalus ursinus (Fischer et al. 2004), Macaca nigra (Neumann et al. 2010)], shows that differences in vocalizations depend mainly on social organization and the reproductive strategy adopted by each species.

To date, few studies have investigated New World monkey vocalization in socio-reproductive contexts. However, a large number [e.g., Leontopithecus rosalia (Benz et al. 1990), Callithrix 
jacchus (Norcross \& Newman 1993), Cebuella pygmaea (Elowson et al. 1991, Elowson \& Snowdon 1993, Snowdon \& de la Torre 2002), Saguinus oedipus (McConnel \& Snowdon 1986, Scott et al. 2005), Callithrix kuhlii (Smith et al. 2009), Brachyteles hypoxanthus (Arnedo et al. 2010), and Brachyteles arachnoides (Ades \& Mendes 1997)] suggest that vocalizations vary according to sex and age in several species. This evidence indicates that even in species where sexual dimorphism is absent, there may be biological constraints, such as morphological differences (Hershkovitz 1977), imposing distinct vocalization repertories on individuals of different sex and age. Bezerra \& Souto (2008) described the calls of common marmosets (C. jacchus) for the first time in wild conditions, showing that, in addition to sex differences, the subject's age influences the type of calls present in their vocal repertoire. The authors conclude that juvenile calls reflect their social status, since they utter submission cries when watching conspecifics, possibly denoting an attempt to get closer to other group members or receive assistance from adults without being rejected (Bezerra \& Souto 2008).

Changes in the social environment may constitute one of the critical features that influence vocal modification in some species. Rukstalis et al. (2003) studied vocalization change in Wied's black tufted-ear marmosets (C. kuhlii) when exposed to new neighbors. They showed that animals exposed to new social contexts undergo significant modifications in the parameters of phee calls, a call type uttered by marmosets on different occasions, such as, to make contact with conspecifics, in order to bring members together (Epple 1968, Winter 1977).

A New World primate genus, well known for its powerful long-distance roars, is the Alouatta spp., also known as the howler monkey (Whitehead 1995). Males have an enlarged hyoid bone, which surrounds a hyolaryngeal apparatus that functions as a resonance chamber (Kelemen \& Sade 1960), amplifying their roars. It is known that these vocalizations are used in intergroup communication (Whitehead 1987, Chiarello 1995, Kitchen 2004), but it is still unclear how they use these signals to communicate in their own groups. Hence, Holzmann et al. (2012) tested three hypotheses to evaluate the ultimate function of roaring (howling) behavior: i) roars are used to gain exclusive access to food; ii) roars ensure exclusive access to mates; iii) roaring behavior serves to avoid male takeovers and infanticide. The authors recorded the roaring behavior of two groups of Alouatta caraya and Alouatta guariba clamitans over a 12 -month period. The results did not support the food defense or infanticide avoidance hypothesis, but did corroborate the mate defense theory.

In summary, acoustic signals might be very important for primate communication, particularly in arboreal species, given that their social and physical environments require a signal that can deviate from obstacles and exhibit directionality. The study of acoustic communication in socio-sexual contexts in primates has involved numerous species of Old World monkeys and a few of New World monkeys. The focus on New World monkey communication has been on the physical structure of calls, but their function is still poorly known.

\section{CHEMICAL COMMUNICATION}

The general consensus regarding primates is that they are "visual" animals (Laska et al. 2000). Apes and Old World monkeys use more visual communication such as color vision and facial expressions as well as tactile and vocal communication (Epple 1974, Laska et al. 2000) rather than chemical communication. However, New World monkeys are known to primarily use chemical signals to communicate (Epple 1976, Epple 1973, Epple 1986).

As described by Johnson (1973), scent marking is the behavior by which glandular secretions are deposited on the ground or onto objects in an animal's environment. Moreover, the deposition of urine and feces can also constitute marking behavior (Ewer 1968, Rails 1971) and is part of an animal's olfactory communication system.

In an attempt to explain the difference between Old World and New World monkeys in the use of chemical communication, Gilad et al. (2004) found that Old World monkeys and the howler monkey, a New World primate, have a significantly higher proportion of olfactory receptor pseudogenes (genes that have lost their coding ability or are no longer expressed in the cell) than other New World monkeys or the lemur, a prosimian. The authors suggest that the deterioration of the olfactory repertoire occurred concomitantly with the acquisition of full trichromatic color vision in Old World primates and the howler monkey and might be an exchange in the importance of these two senses in 
primate evolution. Contradicting this hypothesis, Dong et al. (2009) concluded that the reduced olfaction ability in apes and Old World monkeys cannot be explained by the higher number of pseudogenes or by fewer functional olfactory genes because of the extensive birth-and-death processes (whose gene families expand by duplication and contract by deletion), and that such variations in number of pseudogenes did not cause a significant difference in the number of intact and functional olfactory receptor genes in individual primate genomes.

Despite the discussion about the possible tradeoff between the gain and loss of these two senses, some studies suggest a broader role for scent communication in Old World monkeys than is currently recognized, especially concerning socio-sexual contexts. Setchel et al. (2010) compared scent profiles of mandrills (Mandrillus sphinx) with the features of signalers and found that scents can transmit variable information such as age and male dominance as well as fixed information such as sex. However, the authors could not find scent signals for either female cycle or rank, suggesting that chemical signals have different importance between males and female mandrills. Other evidence that olfactory cues are important to Catarrhines was reported by Freeman et al. (2012), who studied chest rubbing behavior in vervet monkeys (Chlorocebus aethiops). They found that chest rubbing behavior is associated with higher ranking males, who are more likely to engage in such behavior during the breeding season in areas where territorial encounters occur, indicating that this behavior may be involved in intrasexual competition. The authors report that, although they could not perform histological analysis of skin from the chest region or analysis of any substance transferred onto tree trunks via chest rubbing, this behavior very likely represents scent marking.

In New World monkeys, the presence of scent glands in the sternal and anogenital regions (Epple \& Lorenz 1967, Perkins 1975, Zeller et al. 1988), a functional vomeronasal organ (Maier 1982), in addition to behavioral evidence, suggests that chemical signals are widely used for socio-sexual communication. Indeed, several endocrinological, behavioral and chemical composition studies have provided evidence for chemical communication in a number of species [C. jacchus and S. oedipus (Abbott et al. 1993), C. pygmaea (Converse et al. 1995), C. jacchus (Smith
\& Abbott 1998), S. oedipus (Ziegler et al. 1993a, 1993b, 2005), L. rosalia (Miller et al. 2003)].

Ziegler et al. (1993a) found that male cottontop tamarins ( $S$. oedipus) responded to ovulatory signals when presented with the scents of a novel, ovulating female, with behavioral arousal indicating reception of these signals. This contradicted the longheld idea that ovulation was concealed. In 2004, Ziegler et al. reported changes in male urinary androgens that occurred simultaneously with the follicular phase, resulting in an increase in male fertility. Moreover, this is the period when estrogens are elevated and female scent-marking increases (Ziegler et al. 1993b). Ziegler et al. (2004) report that, due to high offspring mortality, a high reproductive rate is important for this species and requires a clear signaling process to indicate fertility. Furthermore, since a large number of breeding males participate in infant care when females are ovulating after parturition, the former will be in close enough proximity to respond to such signals (Ziegler et al. 2004).

Interestingly, Ziegler et al. (2005) found that single and pair-housed male marmosets demonstrated behavioral arousal when presented with the scents of novel periovulatory females and a significant elevation in serum testosterone levels related to vehicle control scents. However, an additional group of males who were fathers at the time of testing did not respond behaviorally and showed a minimal hormonal response to the scents of novel, periovulatory females, demonstrating that something about being a father affected the response to the scent (Ziegler et al. 2005). Additionally, studies with functional imaging of the brain have revealed activation of specific brain areas when female sexual scents are presented to male common marmosets (C. jacchus) (Ferris et al. 2001, Ferris et al. 2006).

Smith \& Abbott (1998) also demonstrated that male common marmosets (C. jacchus) discriminated between scents of periovulatory and anovulatory female marmosets. Furthemore, Snowdon et al. (2011) showed that male common marmosets (C. jacchus) were capable of associating a novel and arbitrary olfactory cue with access to a periovulatory female. These results suggest that the scents of ovulating females are not pheromones (scents that release innate behavioral responses in recipients) and that marmoset males may learn specific characteristics of female scents, providing a possible basis for mate identification. 
Chemical signals are also used to regulate social and reproductive process dominance in New World primates (Epple 1972, French \& Cleveland 1984, Dobroruka 1972, Epple \& Lorenz 1967, Homburg 1989, Abbot et al. 1993, Lazaro-Perea 1999, White et al. 2000, Miller et al. 2003), since dominant individuals scent mark at higher rates than social/reproductive subordinates (Epple 1972, Dobroruka 1972, Epple \& Lorenz 1967, Homburg 1989, White et al. 2000).

Reproductively dominant females can suppress subordinate ovulation using scent marks (Abbott et al. 1993). Intrassexual dominance in golden lion-tamarim (L. rosalia) is communicated through scent marking by males but not by females outside intergroup encounters (Miller et al. 2003). Reproducing adult female aripuana marmosets (Mico intermedius) scent marked more than subordinates (Rylands 1982). However, in C. jacchus and Callithrix flaviceps no differences were recorded between overall rates of scent marking by dominant and subordinate males and females (Lazaro-Perea et al. 1999, Guimaraes 1998). Nor was a pattern found in Saguinus mystax, since in some groups there were differences between scent marking rates while in others there were none (Heymann 1998). However, intersex differences are observed in C. jacchus (Sousa et al. 2006) and Saguinus labiatus (Smith \& Gordon 2002), where females scent mark more frequently than males.

The study of chemical communication in Old World monkeys has been neglected. However, new evidence shows that this communication modality is important in some groups (Setchell et al. 2010, Freeman et al. 2012). Thus, the gap in this sensory modality needs to be filled. On the other hand, the use of chemical signals by New World monkeys is widely known, but information from wild populations is scarce.

\section{VISUAL COMMUNICATION}

Charles Darwin was the first to document human facial expressions and their similarities with other primates in a book entitled "The Expression of Emotions in Man and Animals", published in 1872. Darwin was trying to show how human facial expressions have parallels with the expressions of other animals, providing a behavioral argument for evolutionary continuity. Darwin's theory has been corroborated by a number of behavioral studies showing that facial expressions, as well as gestures and body posture, are used by animals to communicate (De Waal 2003, Pollick \& De Waal 2007, Van Hoof 1967).

A facial expression alone does not indicate whether an individual is aggressive, fearful, or friendly, and such judgments are derived from concomitant behavioral observations (De Waal 2003). Behavioral records are necessary to interpret visual communication, paying attention to the signals, sender and receiver behaviors and the consequences during social interactions. A general assumption about facial expressions is that they can transmit a variety of information about an individual's emotion, motivation or intention (van Hooff 1967, Ekman 1997, Parr et al. 2002).

Jan van Hooff (1967), in one of his first studies, showed that when a female pigtail monkey ( $M$. nemestrina) is in heat, a male may smell her genital region, which is highly swollen. It then exhibits a facial gesture, mainly characterized by protruding lips, and maintains the facial posture for a short time, followed by copulations (Van Hoof 1967). Rhesus macaques (Macaca mulatta) also show facial expressions. This species lives in a social system known to be strict, with a linear dominance hierarchy. Subordinates display bared-teeth behavior (retraction of the lips to expose both rows of teeth) to higher ranking individuals (De Waal and Luttrell 1985). However, the bared-teeth behavior does not have the same meaning in other species (van Hooff 1967, Preuschoft \& van Hooff 1995), which use these displays, sometimes mutually between individuals, to increase social attraction and communicate that there is no risk of aggression (van Hooff 1967, 1976, Waller \& Dunbar 2005). It can also occur during affiliative contexts, such as grooming, sexual solicitation and reconciliations (van Hooff 1973, Preuschoft \& van Hooff 1997, Parr et al. 2002, Waller \& Dunbar 2005).

Some authors propose that the bared-teeth displayed by different species is homologous with the human smile, which means that this behavior can be traced to a common ancestor (van Hooff 1972, Preuschoft \& van Hooff 1997, Waller \& Dunbar 2005). This conclusion is based on the physical similarity between the bared-teeth display and the human smile, as well as on the similar social function of these expressions, indicating appeasement, reassurance, increased social bonding, and its consequent important role in facilitating social cohesion among primates (Preuschoft \& van Hooff 1997). 
Compared to Old World monkeys, their New World counterparts are considered to display poorly developed facial expressions (Moynihan 1976, Hershkovitz 1977). Indeed, they do have a rich repertoire of visual signals, but these may be less noticeable due to their small size (Stevenso \& Poole 1976, Snowdon \& Soini 1988). For example, in the context of sexual behavior, tamarins (Saguinus sp.) and common marmosets ( $C$. jacchus) display rapid tongue-flicking, which appears more frequently during the periovulatory period (Stevenson \& Poole 1976, Snowdon \& Soini 1988). However, tongue-flicking can also be seen during agonistic encounters (Stevenson $\&$ Poole 1976). A common behavior exhibited in intragroup and intergroup agonistic encounters in $C$. jacchus is the 'raised tail' behavior pattern (Stevenson \& Poole 1976). Another visual signal usually displayed by New World monkeys is piloerection, used as a response to the introduction of another individual into a group or to the presence of a potential predator (Mason 1968, Moynihan 1963, 1964, 1970, Stevenson \& Poole 1976), whereby the individual appears larger than it actually is, and then intimidates its adversary (Stevenson \& Poole 1976).

A marked singularity between humans and other primates is the use of manual gestures to communicate (Maestripieri 1996, 1997, 2005, De Waal 2003). This consists of intentional hand movements without the use of objects or substrate (Pollick \& De Waal 2007). The intentional use of manual gestures to influence others has been reported in all great ape species (Tomasellho \& Call 1997). There is clear evidence of flexibility, which means that some gestures can be used across a number of different contexts (Pika \& Tomasello 2002, Liebal et al. 2004, 2006, Pollick \& de Waal 2007, Genty et al. 2009, Hobaiter \& Byrne 2011, Roberts et al. 2012). This flexibility is greater than in vocal communication, because it involves fewer evolutionarily urgent activities (Pika et al. 2005). A consistent association between a given type of gesture and a particular behavioral change may be used to infer the meaning of different gestures, or of the same gesture used in different contexts (Seyfarth et al. 2010). Nonhuman primates communicate using manual gestures mainly in relatively intimate social contexts such as play, grooming, nursing and sexual and agonistic encounters (Pika et al. 2005).

Facial expressions, gestures and body posture are not the only signals used by primates for visual communication. Females of many primate species signal sexual receptivity, which occurs more frequently around the periovulatory phase of the cycle (Bielert 1986, Aujard et al. 1998, Deschner et al. 2004), with changes in the size, shape, turgidity, color and luminance of their perineal skin (Rowell 1972, Dixson 1983).

One of the most notable visual signals is perineal swelling of the skin in the anogenital region and rump around the time of ovulation in many species (Zinner et al. 2004). This exaggerated swelling is an estrogendependent edema of the tissue, with primarily extracellular water retention and some intracellular retention (Krohn \& Zuckermann 1937, Aykroyd \& Zuckermann 1938). Primates of different radiations, such as Callitrichids (Sicchar \& Heymann 1992), howler monkeys (Glander 1980), tarsiers (Wright et al. 1986), patas monkeys (Dixson 1983) and white handed gibbons (Dahl \& Nadler 1992), show sexual swelling. Domb \& Pagel (2001) studied a population of wild olive baboons (Papio cynocephalus anubis) and found that males use the size of sexual swelling to determine their mating effort, fighting more aggressively to consort females with larger swelling, since they live in a multi-male breeding system where there is intense competition for access to females. A study with Barbary macaques (M. sylvanus) showed a significant correlation between sexual swelling sizes and female estrogen levels (Brauch et al. 2007). However, no relation was found with sexual behaviors. The results clearly show that female sexual swelling is a sign of the fertile phase (Brauch et al. 2007).

Color variability has long been thought to be a product of sexual selection and to play an important role in animal communication (Zahavi 1977, 1991, Dawkins \& Krebs 1978, Krebs \& Dawkins 1984, Andersson 1994). Among mammals, primates exhibit striking examples of skin and pelage color variation (Bradley \& Mundy 2008). In many cases, these characteristics convey information about a signaler to a receiver. Such information can be either to a member of the opposite sex, characterizing an intersex competition or mate choice, or to a member of the same sex, that is, intrasex competition. Facial color patterns can also play a role in society and species recognition, as described by Santana et al. (2012) in a recent study in Neotropical primates. The authors found that species living in smaller groups where social interactions are less frequent and in sympatry with a higher number of species from the same genus have 
evolved more complex patterns of facial colors.

A number of authors have proposed that chromatic variations are associated with male competition and struggles for social position (Vandenburgh 1965; Henzi 1985; Gerald 2001). Changizi et al. (2006) argues that skin color assumes an important role in signalization, since it is related to fundamental blood characteristics that are common to all primates. Coloration may play an important role in communication between male vervet monkeys (Cercopithecus aethiops), gelada (Theropithecus gelada) mandrills (M. sphinx) and green monkeys (C. aethiops sabaeus) (Gartlan \& Brain 1968, Dunbar 1984, Setchell \& Dixson 2001, Gerald 2001, Setchel $\&$ Wickings 2005). Signals of status can benefit individuals because they can regulate the degree of costly conflict and even avoid agonistic encounters with the absence of direct interaction (Gerald 2001). In addition to communication between males, male color differences can influence communication between sexes (Cooper \& Hosey 2003, Waitt et al. 2003, Setchel 2005). Contradicting this assertion, Gerald et al. (2007) conducted an experiment modifying scrotal coloration in male vervet monkeys (C. aethiops) and introducing females to these males. The authors found that females pay attention to male coloration, but do not bias their interactions toward males solely on the basis of natural male coloration. In the red-fronted lemur (Eulemur fulvus rufus), a prosimian species, facial hair coloration is related to male quality, but no relation was found for reproductive success or dominance rank.

Chromatic variations in female sexual skin are regulated by ovarian estrogen (Czaja et al. 1975, Herbert 1966), which increases vascular blood flow under the skin surface, thereby signaling the fertile phase in many species of Old World monkeys. It has long been thought that color variation in sexual skin plays a role in stimulating male sexual interest. However, few studies have tested this hypothesis. In 1989, Bielert et al. showed for the first time that female red swelling elicited a significant male masturbatory response in chacma baboon males (Papio ursinus). In 2006, Waitt et al. demonstrated that rhesus macaque male (M. mulatta) visual preferences are influenced by the color of the anogenital skin, but not female facial color, indicating that displays of red coloration in non facial skin alone are not sufficient to elicit the attention of males.
However, sexual skin color of the face and hindquarters has been associated with intrasexual communication and this clue can be used to monitor another female reproductive status or cyclic phase for competitive purposes (Gerald et al. 2007), or even to convey social intentions toward other females (Gerald et al. 2009). In some primate species, females exhibit chromatic variation during pregnancy in their faces and anogenital regions, as documented in Lophocebus albigena (Rowell \& Chalmers 1970), Theropithecus gelada (Dunbar 1977) and Papio cynocephalus (Altmann 1973). Gerald et al. (2009) demonstrated for the first time that pregnancy coloration in rhesus macaques ( $M$. mulatta) contains information about reproductive status and might be an attention-grabbing stimulus to males and a warning stimulus to both male and female rhesus macaques.

To date, only one study has investigated sociosexual communication by chromatic signals in a New World primate. Oliveira (2009) studied common marmosets (C. jacchus) and found a relation between chromatic variation on female skin and fecal progesterone. Using color vision models (Vorobyev \&Osorio 1998), he suggests that these chromatic signals can be detected by males. A possible reason for the negligence of this type of study in Platyrrhini is that the bodies of the vast majority of New World monkeys are covered with hair, and that bare skin should be a premise to perceiving skin color variation (Changizi et al 2006). However, this should be reviewed, given that New World primates have a few hairless areas on their bodies. Moreover, New World monkeys have different color vision than their Old World counterparts. The former typically have polymorphic color vision, which provides individuals with any of several distinct types of color vision, including both trichromatic and dichromatic variants (Jacobs 2007), while Old World monkeys are routine trichromats (Jacobs \& Deegan 1999).

Luminance, a visual signal that has been neglected, may be used as a socio-sexual signal. Highman et al. (2010) used vision models and found luminance changes outside the fertile period in female rhesus macaques ( $M$. mulatta) that could lead to paternity confusion. The authors highlight the importance of considering receiver perception instead of using field data collected by digital photography, since the latter can be misleading when values are unrelated to the visual system of the beholder. Thus, studies on chromatic and 
luminance variation in New World monkeys are needed to improve knowledge of primate visual communication and understand the difference in color vision between New World and Old World primates.

\section{TACTILE COMMUNICATION}

Compared to other sensory modalities, the study of tactile communication in humans and nonhuman primates has been neglected, favoring other modalities, mainly vision. Furthermore, the methodologies used to study it are quite difficult and sometimes even inaccessible to researchers (Hertenstein et al. 2006). However, researchers should give more attention to tactile communication since it has two primacies: phylogenetic primacy, whereby nonverbal communication, such as touch, preceded language in a species' evolutionary history (Dew \& Jensen 1977, Dunbar 1996); and ontogenetic primacy, which states that in the beginning of life, the importance of nonverbal communication, particularly tactile stimulation, supersedes that of verbal communication (Field 2001). The role of tactile communication in primates has been studied with an emphasis on attachment in the motherinfant relationship, contact in post-conflict events and as a social mechanism (Hertenstein et al. 2006).

Grooming, which consists of removing lice, parasites and other objects from the fur with the hands or mouth, is a tactile behavior exhibited by most primates (Hutchins \& Barash 1976, Sparks 1967). The evolutionary origin of this behavior was self-cleaning or even to help conspecifics by cleaning their bodies in places they could not reach (Hutchins \& Barash 1976, McKenna, 1978). In addition to its cleaning function, grooming plays an important role in the maintenance or establishment of social relationships. For this reason, primates may engage in social grooming (allogrooming), self-grooming or even both (Tanaka \& Takefushi1993).

The social factors involved in allogrooming are multifaceted, and include sex, rank and time available for the activity (Hertenstein et al. 2006). In 1977, Seyfarth proposed a model that integrates rank, attractiveness, preference for close relations and time available for grooming, to determine which grooming interactions are most likely. According to the model, higher ranked females may receive more grooming than their lower ranking counterparts. This indeed occurs with most Old World primate species and some New World monkeys (Gouzales \& Gouzoules 1987,
Seyfarth 1977, 1980). However, the model cannot be extrapolated, especially to females. Each species may have its own grooming pattern related to its specific needs (Sambrook et al. 1995). For example, in some species, such as the brown capuchin (Cebus apella), blue monkey (Cercopithecus mitis stuhlmanni), northern plains gray langur (Semnopithecus entellus), wedge-capped capuchin (Cebus olivaceus), rhesus monkey ( $M$. mullata) and common marmoset $(C$. jacchus), allogrooming pattern can be from higher to lower rank, lower to higher or even between females of the same hierarchy status (Borries et al. 1994, Di Bitetti 2000, O'Brien 1993, Parr et al. 1997, Rowell et al. 1991, Lindburg 1973, Lazaro-Perea et al. 2004).

Grooming between males is much more uncommon than between females, because there is generally only one male per group, since groups are usually bound through female lineages and males leave their troops at a young age (Drickamer, 1976). However, in groups with more than one male, the dominant individual is most often groomed (Borries et al. 1994, Terry 1970). Grooming between males can also occur in order to avoid aggression when there is competition for dominance, as occurs in chimpanzees (Pan troglodytes) (Goodall 1986).

During sexual interactions, the increased contact, grooming and proximity behaviors between males and females influence the likelihood of reproduction (Epple 1977, Sousa et all. 1977, Maestripieri \& Wallen 1997). Females tend to choose males that give reciprocal attention in grooming (Goodal 1986, Michel et al. 1976, Smuts 1987, Tutin 1979). In common marmosets ( $C$. jacchus), the higher grooming rates between the breeding pair, associated to coordinated behaviors, such as piloerection, are important indicators of the existence of pair bonding between males and females (Silva \& Souza 1997).

Primate societies form permanent associations between individuals. The existence of these associations means that conflicts must be regulated so that they do not weaken relationships (De Waal \& Aureli 1996). Conflicts can be regulated by reconciliation and consolation, such as post-conflict contacts that serve to repair social relationships and reassure distressed individuals. Physical contacts during reconciliation include grooming, mounting, and clasping (Thierry 1984). These promote physical and emotional homeostasis (De Waal 1993) by reducing the uncertainty that new aggressions between 
conspecifics will occur (Silk 2002). Reconciliation contacts have been evidenced in over 20 primate species (Aureli \& De Waal 2000).

Another way to regulate post-conflict stress is consolation, consisting of affective contact between recipients of aggression and non-opponent third parties (bystanders) (De Waal \& Aureli 1997). This phenomenon is rare in the animal kingdom and among primates it has been documented in chimpanzees (Pan troglodytes; De Waal \& Van Roosmalen 1979, Fraser et al. 2008, Romero \& De Waal 2010, Romero et al. 2011) bonobos (Pan paniscus; Palagi et al. 2004, Clay $\&$ De Waal 2013) and gorillas (Gorilla gorilla; Cordoni et al. 2006, Mallavarapu et al. 2006). Consolation behaviors, which can be affiliative, include expressions of empathy such as touching, embracing, and kissing (Romero et al. 2010).

Finally, an inherent characteristic of mammals is the relationship between mother and infant, given that during intrauterine development and after birth they are physically closely related. Tactile communication plays an important role in the attachment between them, as first described by Harlow \& Harlow (1962), who demonstrated that infant rhesus macaques ( $M$. mulatta) find contact comfort more appealing than feeding alone, indicating that touch may be the primary mechanism of attachment. Recently, Clay and De Waal (2013) studied post-conflict interactions in bonobos, and found that mother-reared individuals are significantly more involved in post-conflict interactions than orphans. The authors conclude that maternal care in infancy is critical for the development of secure and organized attachment styles as well as for cognitive and socio-emotional development. Moreover, contact behaviors are also important in the development of parental care in common marmosets $(C$. jacchus), since they are related to an increase in plasma prolactin in parents that carry their offspring (Dixson \& George 1982, Mota \& Sousa 2000).

Touch seems to be very important in primate communication. It is used in different contexts and plays an important role in primate development. Therefore, future studies on this modality are necessary, since it is an important key to understanding human and nonhuman communication.

\section{CONCLUSIONS}

As presented in this review, primates use different modalities to communicate with conspecifics in socio- sexual contexts and evidence was found elucidating all four sensory modalities (acoustic, chemical, visual and tactile). We observed gaps in the study of each modality, mainly because of the much larger number of studies on Old World primates compared to their New World counterparts for each sensory modality.

The use of each sense depends on the social and physical environment, the receiver's sensory system and the context. Because of these limitations, primates usually use more than one modality to transmit information. Thus, we cannot affirm that one sensory modality is more important than another, since the animal may use more than one type of signal to communicate.

In addition to acquiring knowledge per se, studying the way nonhuman primates use various signals to communicate and the shared modalities between the species helps us understand human communication and how nonhuman primates are closely related to humans, sharing anatomic, physiological and behavioral characteristics. The study of the evolution of language represents an exciting and rapidly growing field, and comparative data will continue to play a fundamental role on it.

Finally, by understanding how primate species perceive the world and communicate among themselves, researchers can design and refine experiments, housing, husbandry systems and enrichment strategies, in order to ensure their wellbeing and improve conservation programs.

ACKNOLEDGEMENTS: Laís A.A. Moreira received scholarship grants from CAPES Foundation. We would like to thank Matheus M. Andreozzi for his helpful comments and insights during the preparation of this review.

\section{REFERENCES}

ABBOTT, D.; BARRETT, J. \& GEORGE, L. 1993. Comparative aspects of the social suppression of reproduction in female marmosets and tamarins. Pp. 152-163. In: A.B. Rylands (ed.). Marmosets and tamarins: systematics, behaviour, and ecology. Oxford: Oxford University Press. 396 p.

ADES, C. \& MENDES, F.D.C. 1997. Uma aproximação às vocalizações do muriqui (Brachyteles arachnoides). Temas em Psicologia, 3: 135-149.

ALTMANN, S.A. 1973. The pregnancy sign in savannah baboons. The Journal of Zoo Animal Medicine, 4: 8-12.

ANDERSSON, M. 1994. Sexual selection. Princeton University Press, Princeton. 624 p. 
ARNEDO, L.F.; MENDES, F.D.C. \& STRIER, K.B. 2010. Sex Differences in Vocal Patterns in the Northern Muriqui (Brachyteles hypoxanthus). American Journal of Primatology, 72: 122-128.

ARNOLD, K. \& ZUBERBUHLER, K. 2006a. The alarm-calling system of adult male putty-nosed monkeys, Cercopithecus nictitans martini. Animal Behaviour, 72: 643-653. http://dx.doi.org/ 10.1016/j.anbehav.2005.11.017.

ARNOLD, K. \& ZUBERBUHLER,K. 2006b. Semantic combinations in primate calls. Nature 441:303. http://dx.doi.org/ $10.1038 / 441303 a$.

AUJARD, F.; HEISTERMANN, M.; THIERRY, B. \& HODGES, J.K. 1998. Functional significance of behavioural, morphological, and endocrine correlates across the ovarian cycle in semifree ranging female Tonkean macaques. American Journal of Primatology, 46: 285-309. http://dx.doi.org/10.1002/ (SICI) 10982345(1998)46:4<285::AID-AJP2>3.0.CO;2-8 .

AURELI, F. \& DE WAAL F.B.M. 2000. Natural conflict resolution. Berkeley: University of California Press. 424 p.

AYKROYD, O.E. \& ZUCKERMANN, S. 1938. Factors in sexualskin oedema. The Journal of Physiology, 94: 13-25.

BENZ, J.J.; FRENCH J.A. \& LEGER D.W. 1990. Sex differences in vocal structure in a callitrichid primate, Leontopithecus rosalia. American Journal of Primatology, 21: 257-264. http://dx.doi.org/ 10.1002/ajp.1350210402.

BEZERRA, B.M. \& SOUTO, A. 2008. Structure and Usage of the Vocal Repertoire of Callithrix jacchus. International Journal of Primatology, 29: 671-701. http://dx.doi.org/10.1007/s10764008-9250-0.

BIELERT, C. 1986. Sexual interactions between captive adult male and female chacma baboons (Papio ursinus) as related to the female's menstrual cycle. Journal of Zoology, 209: 521-536. http:/ /dx.doi.org/10.1111/j.1469-7998.1986.tb03608.x .

BORRIES, C.; SOMMER, V. \& SRIVASTAVAA. 1994. Weaving a tight social net: Allogrooming in free-ranging female langurs (Presbytis entellus). International Journal of Primatology, 15: 421443. http://dx.doi.org/10.1007/BF02696102 .

BRADBURY, J. W. \& VEHRENCAMP, S.L. 1998. Principles of animal communication. Sinauer Associates. First Edition. 882p.

BRADBURY, J. W. \& VEHRENCAMP, S.L. 2011. Principles of animal communication. Sinauer Associates. Second Edition. 697p.

BRADLEY, B.J. \& MUNDY, N.I. 2008. The Primate Palette: The Evolution of Primate Coloration. Evolutionary Anthropology, 17: 97-111. http://dx.doi.org/10.1002/evan.20164 .

BRAUCH, K.; PFEFFERLE, D.; HODGES, K.; MÖHLE, U.; FISCHER, J. \& HEISTERMANN, M. 2007. Female sexual behavior and sexual swelling size as potential cues for males to discern the female fertile phase in free-ranging Barbary macaques (Macaca sylvanus) of Gibraltar. Hormones and Behavior, 52: 375-383. http://dx.doi.org/10.1016/j.yhbeh.2007.06.001 .
CARTMILL, E. \& MAESTRIPIERI, D. 2012. Socio-cognitive specializations of nonhuman primates: evidence from gestural communication. Pp. 166-193. In: J. Vonk \& T. Shackelford (eds.). The Oxford Handbook of Comparative Evolutionary Psychology. Oxford: Oxford University Press. http://dx.doi.org/10.1093/ oxfordhb/9780199738182.013.0010 .

CASTRO, D.C.; SOUSA, M.B.C.; COSTA, M.P. \& DRANCO, C.M.N. 1998. Características da marcação de cheiro em grupos familiares do Callithrix jacchus em cativeiro. Pp. 64-64. In: XVI Encontro Anual de Etologia. Resumos de Etologia. São José do Rio Preto, SP.

CHANGIZI, M.A.; ZHANG, Q. \& SHIMOJO, S. 2006. Bare skin, blood and the evolution of primate colour vision. Biology Letters, 2: 217-221. http://dx.doi.org/10.1098/rsbl.2006.0440 .

CHIARELLO, A. G. 1995. Role of loud calls in brown howler monkeys, Alouatta fusca. American Journal of Primatology, 36: 213-222. http://dx.doi.org/10.1002/ajp.1350360305 .

CLAY, Z. \& DE WAAL, F.B.M. 2013. Bonobos Respond to Distress in Others: Consolation across the Age Spectrum. PLOS ONE, 8(1): e55206. http://dx.doi.org/10.1371/journal.pone.0055206 .

CONVERSE, L.J.; CARLSON, A.A.; ZIEGLER, T.E. \& SNOWDON, C.T. 1995. Communication of ovulatory state to mates by female pygmy marmosets, Cebuella pygmaea. Animal Behavior, 49: 615-621. http://dx.doi.org/10.1016/00033472(95)80194-4.

COOPER, V.J. \& HOSEY, G.R. 2003. Sexual dichromatism and female preference in Eulemur fulvus subspecies. International Journal of Primatology, 4: 1177-1188. http://dx.doi.org/10.1023/ B:IJOP.0000005986.21477.ad .

CORDONI, G.; PALAGI, E. \& TARLI, S.B. 2006. Reconciliation and consolation in captive western gorillas. International Journal of Primatology, 27: 1365-1382. http://dx.doi.org/10.1007/s10764$\underline{00690784}$.

CZAJA, J.A.; EISELE, S.G. \& GOY, R.W. 1975. Cyclical changes in the sexual skin of female rhesus: relationships to mating behaviour and successful artificial insemination. Federation Proceedings, 34: 1680-1684.

DAHL, J.F. \& NADLER R.D. 1992. Genital Swelling in Females of the Monogamous Gibbon, Hylobates (H) lar. American Journal of Physical Anthropology, 89: 101-108. http://dx.doi.org/10.1002/ ajpa. 1330890109 .

DARWIN, C. 1998. The Expression of the Emotions in Man and Animals, $3^{\text {rd }}$ edit. P. Ekman, Ed. Oxford University Press. New York. 368p.

DAWKINS, R. \& KREBS, J.R. 1978. Animal signals: information or manipulation? Pp. 282-309. In: J. R. Krebs \& N. B. Davies (eds.). Behavioural Ecology: an Evolutionary Approach. Oxford, Blackwell Scientific. 464p.

DE WAAL, F.B.M. \& AURELI, F. 1996. Consolation, 
reconciliation, and a possible cognitive difference between macaques and chimpanzees. Pp. 80-110. In: A.E. Russon, K.A. Bard \& S. Taylor Parker (eds.). Reaching into thought: The minds of great apes. Cambridge: Cambridge University Press.

DE WAAL, F.B.M. \& AURELI, F. 1997. Conflict resolution and distress alleviation in monkeys and apes. Pp. 317-328. In: C.S. Carter, B. Kirkpatric \& I. Lenderhendler (eds.). The Integrative Neurobiology of Affiliation. New York: New York Academy of Sciences.

DE WAAL, F.B.M. \& LUTTRELL, L.M. 1985. The formal hierarchy of rhesus monkeys: an investigation of the bared-teeth display. American Journal of Primatology, 9: 73-85. http:// dx.doi.org/10.1002/ajp.1350090202.

DE WAAL, F.B.M. \& VAN ROOSMALEN A. 1979. Reconciliation and consolation among chimpanzees. Behavioral Ecology and Sociobiology, 5: 55-66. http://dx.doi.org/10.1007/BF00302695.

DE WAAL, F.B.M. 1993. Reconciliation among primates: A review of empirical evidence and unresolved issues. Pp.111-144. In: W.A. Mason \& S.P. Mendoza (eds.). Primate Social Conflict. Albany: State University New York Press.

DE WAAL, F.B.M. 2003. Darwin's Legacy and the Study of Primate Visual Communication. Annals of the New York Academy of Sciences, 1000: 7-31. http://dx.doi.org/10.1196/annals.1280.003 .

DESCHNER, T.; HEISTERMANN, M.; HODGES, K. \& BOESCH, C. 2004. Female sexual swelling size, timing of ovulation, and male behavior in wild West African chimpanzees. Hormones and Behavior, 46: 204-215. http://dx.doi.org/10.1016/ j.yhbeh.2004.03.013.

DEW, D. \& JENSEN, P.J. 1977. Phonetic processing: The dynamics of speech. Columbus, OH: Merrill. Charles E. Merrill Publishing Company.

DI BITETTI, M.S. 2000. The distribution of grooming among female primates: Testing hypotheses with the Shannon-Wiener diversity index. Behaviour, 137: 1517-1540. http://dx.doi.org/ 10.1163/156853900502709.

DI BITETTI, M. S. 2005. Food-associated calls and audience effects in tufted capuchin monkeys, Cebus apella nigritus. Animal Behaviour. 69: 911-919. http://dx.doi.org/10.1016/ j.anbehav.2004.05.021.

DIXSON, A. F 1983. Observations on the evolution and behavioral significance of 'sexual skin' in female primates. Advances in the Study of Behavior, 13: 63-106.

DIXSON, A.F. \& GEORGE, L. 1982. Prolactin and parental behavior in a male New World primate. Nature, 299: 551-553. http://dx.doi.org/10.1038/299551a0 .

DOBRORUKA, L. 1972. Social communication in the brown capuchin. International Zoo Yearbook, 12:43-45. http://dx.doi.org/ 10.1111/j.1748-1090.1972.tb02262.x .

DOMB, L.G. \& PAGEL, M. 2001. Sexual swellings advertise female quality in wild baboons. Nature, 410: 204-206. http:// dx.doi.org/10.1038/35065597.

DONG, D.; HE, G.; ZHANG, S. \& ZHANG, Z. 2009. Evolution of Olfactory Receptor Genes in Primates Dominated by Birthand-Death Process. Genome Biology and Evolution, 1: 258-264. http://dx.doi.org/10.1093/gbe/evp026.

DRICKAMER, L.C. 1976. Quantitative observations of grooming behavior in free-ranging Macaca mulatta. Primates, 17: 323-335. http://dx.doi.org/10.1007/BF02382789 .

DUNBAR, R.I.M. 1977. Age-dependent changes in sexual skin colour and associated phenomena of female gelada baboons. Journal of Human Evolution, 6: 667-672. http://dx.doi.org/10.1016/ S0047-2484(77)801371.

DUNBAR, R.I.M. 1984. Reproductive decisions: an economic analysis of gelada baboon social strategies. International Journal of Primatology, 8: 197-198.

DUNBAR, R.I.M. 1996. Grooming, gossip, and the evolution of language. Cambridge, MA: Harvard University Press. 242p.

DUSENBERY, D.B. 1992. Light. Pp.145-202. In: D.B. Dusenbery (ed.). Sensory Ecology: How Organisms Acquire and Respond to Information. First edition. W.H. Freeman \& Company. 558p.

EKMAN, P. 1997. Should we call it expression or communication? Innovations in Social Science Research, 10: 333-44. http:// dx.doi.org/10.1080/13511610.1997.9968538.

ENGELHARDT, A.; FISCHER, J.; NEUMANN, C.; PFEIFER, J.B. \& HEISTERMANN, M. 2011. Information content of female copulation calls in wild long-tailed macaques (Macaca fascicularis). Behavioral Ecology and Sociobiology, 2012. 66: 121134. http://dx.doi.org/10.1007/s00265-011-1260-9 .

EPPLE, G. \& LORENZ, R. 1967. Vorkommen, Morphologie und Funktion der Sternaldrüse beiden Platyrrhini. Folia Primatologica, 7: 98-126. http://dx.doi.org/10.1159/000155112 .

EPPLE, G. 1968. Comparative studies on vocalization in marmoset monkeys (Hapalidae). Folia Primatologica, 8: 1-40. http://dx.doi.org/10.1159/000155129.

EPPLE, G. 1972. Social communication by olfactory signals in marmosets. International Zoo Yearbook, 12: 36-42. http:// dx.doi.org/10.1111/j.1748-1090.1972.tb02261.x .

EPPLE, G. 1973. The Role of Pheromones in the Social Communication of Marmoset Monkeys (Callithricidae). Journal of reproduction and fertility, 19: 447-454.

EPPLE, G. 1974. Olfactory Communication in South American Primates. Annals of the New York Academy of Sciences, 237: 261278. http://dx.doi.org/10.1111/j.1749-6632.1974.tb49861.x .

EPPLE, G. 1976. Chemical Communication and Reproductive Processes in Nonhuman primates. Mammalian Olfaction and Reproductive Processes and Behavior, 257-282.

EPPLE, G. 1977. Notes on the establishment and maintenance of 
the pair bond in Saguinus fuscicollis. Pp. 231-237. In: D.G. Kleiman (ed.) The Biology and Conservation of the Callithrichidae. Washington: Smithsonian Institution Press.

EPPLE, G. 1986. Communication by Chemical Signals. Pp. 531580. In: G. Mitchell \& J. Erwin. Comparative Primate Biology, New York.

EWER, R.F. 1968. Ethology of Mammals. Plenum Press, New York.

FEDUREK, P. \& SLOCOMBE, K.E. 2011. Primate Vocal Communication: A Useful Tool for Understanding Human Speech and Language Evolution? Human Biology, 83: 153-173. http:// dx.doi.org/10.3378/027.083.0202.

FERRIS, C.F.; SNOWDON C.T.; KING, J.A.; DUONG, T.Q.; ZIEGLER, T.E.; UGURBIL, K.; LUDWIG, R.; SCHULTZDARKEN, N.J.; WU, Z.; OLSON, D.P.; SULLIVAN JR, J.M.; TANNENBAUM, P.L. \& VAUGHAN, J.T. 2001. Functional imaging of brain activity in conscious monkeys responding to sexually arousing cues. Neuro Report, 12: 2231-2236. http:// dx.doi.org/10.1097/00001756-200107200-00037.

FERRIS, C.F.; SNOWDON, C.T.; KING J.A.; SULLIVAN JR, J.M.; ZIEGLER, T.E.; OLSON, D.P.; SCHULTZ-DARKEN, N.J.; TANNENBAUM, P.L.; LUDWIG, R.; WU, Z.; EINSPANIER, A.; VAUGHAN, T. \& DUONG, T.Q. 2004. Activation of Neural Pathways Associated with Sexual Arousal in Non-Human Primates. Journal of Magnetic Resonance Imaging, 19: 168-175. http://dx.doi.org/10.1002/jmri.10456 .

FIELD, T.M. 2001. Touch. Cambridge, MA: MIT Press.

FISCHER, J.; KITCHEN, D.M.; SEYFARTH, R.M. \& CHENEY, D.L. 2004. Baboon loud calls advertise male quality: acoustic features and their relation to rank, age, and exhaustion. Behavioral Ecology and Sociobiology, 56: 140-148. http://dx.doi.org/10.1007/ s00265-003-0739-4 .

FRASER, O.N.; STAHL, D. \& AURELI, F. 2008. Stress reduction through consolation in chimpanzees. Proceedings of the National Academy of Sciences, 105: 8557-8562. http://dx.doi.org/10.1073/ pnas.0804141105.

FREEMAN, N.J.; PASTERNAK, G.M.; RUBI, T.L.; BARRETT, L. \& HENZI, S.P. 2012. Evidence for scent marking in vervet monkeys? Primates, 53: 311-315. http://dx.doi.org/10.1007/ s10329-012-0304-8.

FRENCH, J. \& CLEVELAND, J. 1984. Scent-marking in the tamarin, Saguinus oedipus: sex differences and ontogeny. Animal Behaviour, 32: 615-623. http://dx.doi.org/10.1016/S00033472(84)80299-7.

GARTLAN, J.S. \& BRAIN, C.K. 1968. Ecology and social variability in Cercopithecus aethiops and C. mitis. Pp 253-292 In: J. Jay (ed.). Primates. Holt, Rinehart and Winston, New York.

GEISSMAN, T. 1987. A sternal gland in the siamang gibbon (Hylobates syndactylus). International Journal of Primatology,

\section{8:1-15. http://dx.doi.org/10.1007/BF02737111 .}

GENTY, E.; BREUER, T.; HOBAITER, C. \& BYRNE, R. W. 2009. Gestural communication of the gorilla (Gorilla gorilla): repertoire, intentionality and possible origins. Animal Cognition, 12: 527-546. http://dx.doi.org/10.1007/s10071-009-0213-4 .

GERALD, M.S.; BERNSTEIN, J.; HINKSON, R. \& FOSBURY, R. 2001. A formal method for objective assessment of primate color. American Journal of Primatology, 53: 79-85. http:// dx.doi.org/10.1002/10982345(200102)53:2<79::AIDAJP3>3.0.CO;2-N .

GERALD, M.S.; WAITT, C. \& LITTLE, A.C. 2009. Pregnancy coloration in macaques may act as a warning signal to reduce antagonism by conspecifics. Behavioural Processes, 80: 7-11. http://dx.doi.org/10.1016/j.beproc.2008.08.001 .

GERALD, M.S.; WAITT, C.; LITTLE, A.C. \& KRAISELBURD, E. 2007. Females pay attention to female secondary sexual color: an experimental study in Macaca mulatta. International Journal of Primatology, 28: 1-7. http://dx.doi.org/10.1007/s10764-0069110-8.

GILAD, Y; WIEBE1, V; PRZEWORSKI1, M; LANCET, D \& SVANTE PÄÄBo. 2004. Loss of Olfactory Receptor Genes Coincides with the Acquisition of Full Trichromatic Vision in Primates. PLoS Biology, 2: 120-125. http://dx.doi.org/10.1371/ journal.pbio.0020005 .

GLANDER, K.E. 1980. Reproduction and population growth in free-ranging mantled howling monkeys. American Journal of Physical Anthropology, 53: 25-36. http://dx.doi.org/10.1002/ ajpa.1330530106.

GOODALL, J. 1986. The chimpanzees of Gombe: Patterns of behavior. Cambridge, MA: The Belknap Press of Harvard University Press.

GOUZOULES, H; GUST, D.A, DONAGHEY, B; \& ANDRE, E.St. 1998. Estrus vocalizations in two primate species (Cercocebus torquatus atys and Macaca nemestrina): evidence for an effect of intrasexual competition. Evolution of Communication, 2: 189-215. http://dx.doi.org/10.1075/ eoc.2.2.03gou.

GOUZOULES, S. \& GOUZOULES H. 1987. Kinship. Pp. 299305. In: B.B. Smuts, D.L. Cheney, R.M. Seyfarth, R.W. Wrangham \& T.T. Struhsaker (eds.). Primate societies.Chicago: University of Chicago Press.

GUIMARAES A. 1998. Ecologia, comportamento reprodutivo e marcacao de cheiro em um grupo de Callithrix flaviceps (Callitrichidae, Primates).Dissertation, Universidade Federal de Minas Gerais, Belo Horizonte, Brasil. 162p.

HARLOW, H.F. \& HARLOW, M.K. 1962. The effect of rearing conditions on behavior. Bulletin of the Menninger Clinic, 26: 213-224.

HAUSER, M.; CHOMSKY, N. \& FITCH, W. T. 2002. The 
faculty of language: what is it, who has it, and how did it evolve? Science, 298: 1569-1579. http://dx.doi.org/10.1126/ science.298.5598.1569.

HENZI, S.P. 1985. Genital signalling and the coexistence of male vervet monkeys (Cercopithecus aethiops pygerythrus). Folia Primatologica, 45: 129-147. http://dx.doi.org/10.1159/ 000156225 .

HERSHKOVITZ, P. 1977. Living New World Monkeys (Platyrrhini) with an Introduction to Primates, Vol 1. Chicago: The University of Chicago Press.

HERSTENSTEIN, M.J.; VERKAMP, J.M.; KERESTES, A.M. \& HOLMES, R.M. 2006. The communicative funcions of touch in humans, nonhuman primates, and rats: a review and synthesis of the empirical research. Genetic, Social, and General Psychology Monographs, 132: 5-94. http://dx.doi.org/10.3200/ MONO.132.1.5-94

HEYMANN, E.W. 1998. Sex differences in olfactory communication in a primate, the moustached tamarin, Saguinus mystax (Callitrichinae). Behavioral Ecology and Sociobiology, 43: 37-45. http://dx.doi.org/10.1007/s002650050464 .

HEYMANN, E.W. 2010. Coordination in Primate Mixed-Species Groups. Pp. 263-288. In: M. Boos et al. (eds.) Coordination in Human and Primate Groups. http://dx.doi.org/10.1007/978-3-64215355-6 15 .

HIGHAM, J.P.; BRENT, L.J.N.; DUBUC, C.; ACCAMANDO, A.K.; ENGELHARDT, A.; GERALD, M.S.; HEISTERMANN, M. \& STEVENS, M. 2010. Color signal information content and the eye of the beholder: a case study in the rhesus macaque. Behavioral Ecology, 21: 739-746. http://dx.doi.org/10.1093/ beheco/arq047.

HOBAITER, K. \& BYRNE, R. 2011. Serial gesturing by wild chimpanzees: its nature and function for communication. Animal Cognition, 14: 825-838. http://dx.doi.org/10.1007/s10071-0110416-3 .

HOLZMANN, I.; AGOSTINI, I. \& DI BITETTI, M. 2012. Roaring Behavior of Two Syntopic Howler Species (Alouatta caraya and A. guariba clamitans): Evidence Supports the Mate Defense Hypothesis. International Journal of Primatology, 33: 338-355. http://dx.doi.org/10.1007/s10764-012-9583-6.

HOMBURG, I. 1989. Soziale Strukturmerkmale von WeissgesichtSakis (Pithecia pithecia).Thesis. University of Bielefeld, Bielefeld, Germany. 124p.

HUTCHINS, M. \& BARASH, D.P. 1976. Grooming in primates: Implications for its utilitarian function. Primates, 17: 145-150. http://dx.doi.org/10.1007/BF02382848 .

JACOBS, G.H. \& DEEGAN, J.F.II. 1999. Uniformity of colour vision in Old World monkeys. Proceedings of the Royal Society of London, 266: 2023-2028.

JACOBS, G.H. 2007. New World Monkeys and Color.
International Journal of Primatology, 28: 729-759. http:// dx.doi.org/10.1007/s10764-007-9168-y .

JOHNSON, R.P. 1973. Scent marking in mammals. Animal Behaviour, 21: 521-535. http://dx.doi.org/10.1016/S0003$\underline{3472(73) 80012-0}$.

KELEMEN, G. \& SADE, J. 1960. The vocal organ of the howling monkey (Alouatta palliata). Journal of Morphology, 107: 123140. http://dx.doi.org/10.1002/jmor.1051070202 .

KITCHEN, D. M. 2004. Alpha male black howler monkey responses to loud calls: Effect of numeric odds, male companion behaviour and reproductive investment. Animal Behaviour, 67: 125-139. http://dx.doi.org/10.1016/j.anbehav.2003.03.007.

KREBS, J.R. \& DAWKINS, R. 1984. Animal signals: mind-reading and manipulation. Pp. 380-402. In: J.R. Krebs \& N.B. Davies (eds.). Behavioural ecology: an evolutionary approach. Second Edition. Oxford: Blackwell Scientific.

KROHN, P.L. \& ZUCKERMANN, S. 1937. Water metabolism in relation to the menstrual cycle. The Journal of Physiology, 88: 369-87.

LASKA, M.; SEIBT, A. \& WEBER, A. 2000. 'Microsmatic' Primates Revised: Olfactory Sensitivity in the Squirrel Monkey. Chemical Senses, 25: 47-53. http://dx.doi.org/10.1093/chemse/ 25.1.47.

LAZARO-PEREA, C.; ARRUDA, M.F. \& SNOWDON, C.T. 2004. Grooming as a reward? Social function of grooming between females in cooperatively breeding marmosets. Animal Behaviour, 67: 627-636. http://dx.doi.org/10.1016/j.anbehav.2003.06.004 .

LAZARO-PEREA, C.; SNOWDON, C. \& ARRUDA M.F. 1999. Scent-marking behavior in wild groups of common marmosets (Callithrix jacchus). Behavioral Ecology and Sociobiology, 46: 313-324. http://dx.doi.org/10.1007/s002650050625 .

LIEBAL, K.; CALL, J.; TOMASELLO, M. 2004. The use of gestures sequences by chimpanzees. American Journal of Primatology, 64: 377-396. http://dx.doi.org/10.1002/ajp.20087.

LIEBAL, K.; PIKA, S. \& TOMASELLO, M. 2006. Gestural communication of orangutans (Pongo pygmaeus). Gesture, 6: 138. http://dx.doi.org/10.1075/gest.6.1.02lie.

LINDBURG, D.G. 1973. Grooming behavior as a regulator of social interactions in Rhesus monkeys. Pp. 124-148. In: C. R. Carpenter (ed.). Behavioral regulators of behavior in primates. Cranbury, NJ: Bucknell University Press.

MAESTRIPIERI, D. \& RONEY, J.R. 2005. Primate copulation calls and postcopulatory female choice. Behavioral Ecology, 16: 106-113. http://dx.doi.org/10.1093/beheco/arh120 .

MAESTRIPIERI, D. \& WALLEN, K. 1997. Affiliative and submissive communication in Rhesus macaques. Primates, 38: 127-138. http://dx.doi.org/10.1007/BF02382003 .

MAESTRIPIERI, D. 1996. Gestural communication and its 
cognitive implications in pigtail macaques (Macaca nemestrina). Behaviour, 133: 997-1022. http://dx.doi.org/10.1163/ 156853996X00576.

MAESTRIPIERI, D. 1997. The evolution of communication. Language and Communication, 17: 269-277. http://dx.doi.org/ 10.1016/S0271-5309(97)00009-8.

MAESTRIPIERI, D. 2005. Gestural communication in three species of macaques (Macaca mulatta, M. nemestrina, M. arctoides): use of signals in relation to dominance and social context. Gesture, 5: 55-71. http://dx.doi.org/10.1075/ gest.5.1.06mae.

MAIER, W. 1982. Nasal structures in Old and New World primates. Pp 219-241. In: R.L. Ciochon, A.B. Chiarelli (eds.). Evolutionary biology of the New World monkeys and continental drift. New York: Plenum Press.

MALLAVARAPU, S.; STOINSKI, T.; BLOOMSMITH, M. \& MAPLE, T. 2006. Postconflict behavior in captive western lowland gorillas (Gorilla gorilla gorilla). American Journal of Primatology, 68: 789-801. http://dx.doi.org/10.1002/ajp.20279 .

MARYANSKI, A. 1997. Primate communication and the ecology of a language niche. Pp. 191- 209. In: U. Sergestrale \& P. Molnar (eds). Nonverbal communication: Where nature meets culture. First Edition.

MCCONNELL, P.B. \& SNOWDON, C.T. 1986. Vocal interactions between unfamiliar groups of captive cotton-top tamarins. Behaviour, 97: 273-296. http://dx.doi.org/10.1163/ 156853986X00649.

MCGREGOR, P.T. 2008. Communication. Pp. 226-250. In: J.J. Bolhuis \& LA. Giraldeau (eds). The behavior of animals: mechanisms, function, and evolution. Blackwell Publishing, Fourth edition.

MCKENNA, J.J. 1978. Biosocial functions of grooming behavior among the common Indian langur monkey (Presbytis entellus). American Journal of Physical Anthropology, 48: 503-509. http:// dx.doi.org/10.1002/ajpa.1330480409.

MILLER, K.E.; LASZLO, K. \& DIETZ, J.M. 2003. The role of scent marking in the social communication of wild golden lion tamarins, Leontopithecus rosalia. Animal Behavior, 65:795-803. http://dx.doi.org/10.1006/anbe.2003.2105.

MITCHELL, G.D. \& TOKUNAGA, D.H. 1976. Sex differences in nonhuman primate grooming. Behavioural Processes, 1: 335345. http://dx.doi.org/10.1016/0376-6357(76)90015-2 .

MOTA, M.T. \& SOUSA, M.B.C. 2000. Prolactin levels of fathers and helpers related to alloparental care in common marmosets, Callithrix jacchus. Folia Primatologica, 71: 22-26. http:// dx.doi.org/10.1159/000021727.

MOYNIHAN, M. 1964. Some behaviour patterns in Platyrrhine monkeys. I. The night monkey (Aotus trivirgatus) Smithson \& Miscellaneous Collections, 146: 1-84.
MOYNIHAN, M. 1976. The New World Primates: Adaptive Radiation and Evolution of Social Behavior, Languages, and Intelligence. New Jersey: Princeton University Press.

NADLER, R. 1988. Sexual and reproductive behavior. Pp. 105116. In: J. Schwartz (ed.), Orang-Utan Biology. Oxford University Press, New York.

NEUMANN, C.; ASSAHAD, G.; HAMMERSCHMIDT, K.; PERWITASARI-FARAJALLAH, D. \& ENGELHARDT, A. 2010. Loud calls in male crested macaques, Macaca nigra: a signal of dominance in a tolerant species. Animal Behaviour, 79: 187193. http://dx.doi.org/10.1016/j.anbehav.2009.10.026.

NORCROSS, J.L. \& NEWMAN, J.D. 1993. Context and genderspecific differences in the acoustic structure of common marmosets (Callithrix jacchus). American Journal of Primatology, 30: 37-54. http://dx.doi.org/10.1002/ajp.1350300104 .

O'BRIEN, T.G. 1993. Allogrooming behaviour among adult female Wedge-capped Capuchin monkeys. Animal Behaviour, 46: 499510. http://dx.doi.org/10.1006/anbe.1993.1218 .

OLIVEIRA, D.G.R. 2009. Papel de sinais cromáticos na identificação de parceiros sexuais em sagüi comum (Callithrix jacchus). Dissertation. Universidade Federal do Rio Grande do Norte, Natal, Rio Grande do Norte. 102p.

PALAGI, E.; PAOLI, T. \& TARLI S.B. 2004. Reconciliation and consolation in captive bonobos (Pan paniscus). American Journal of Primatology, 62: 15-30. http://dx.doi.org/10.1002/ajp.20000 .

PARR, L.A.; MATHESON, M.D.; BERNSTEIN, I.S. \& DE WAAL, F.B.M. 1997. Grooming down the hierarchy: Allogrooming in captive brown capuchin monkeys (Cebus apella). Animal Behaviour, 54: 361-367. http://dx.doi.org/10.1006/ anbe.1996.0419.

PARR, L.A.; PREUSCHOFT, S. \& DE WAAL, F.B.M. 2002. Afterword: research on facial emotion in chimpanzees, 75 years since Kohts. Pp. 411-52. In: F.B.M. de Waal (ed.). Infant Chimpanzee and Human Child. New York: Oxford University Press.

PERKINS, E. 1975. Phylogenetic significance of the skin of New World monkeys (order Primates, infraorder Platyrrhini). American Journal of Physical Anthropology, 42: 395-424. http://dx.doi.org/ 10.1002/ajpa.1330420307.

PFEFFERLE, D.; BRAUCH, K.; HEISTERMANN, M.; HODGES, J.K. \& FISCHER, J. 2008a. Female Barbary macaque (Macaca sylvanus) copulation calls do not reveal the fertile phase but influence mating outcome. Proceedings of the Royal Society B: Biological Sciences, 275: 571-578. http://dx.doi.org/10.1098/ rspb.2007.1499.

PFEFFERLE, D.; HEISTERMANN, M.; HODGES, J.K.; \& FISCHER, J. 2008b. Male Barbary macaques eavesdrop on mating outcome: a playback study. Animal Behaviour, 75: 1885-1891. http://dx.doi.org/10.1016/j.anbehav.2007.12.003 .

PIKA, S. \& TOMASELLO, M. 2002. Gestural communication 
in gorillas (Gorilla gorilla) and bonobos (Pan paniscus) in captivity: a comparison. Thesis. Münster: Westfälische Wilhelms-Universität.

PIKA, S.; KATJA, L. \& TOMASELLO, M. 2003. Gestural communication in young gorillas (Gorilla gorilla): Gestural repertoire and use. American Journal of Primatology, 60: 95-111. http://dx.doi.org/10.1002/ajp.10097.

PIKA, S.; LIEBAL, K. \& TOMASELLO, M. 2005. Gestural communication in subadult bonobos (Pan paniscus): Repertoire and Use. American Journal of Primatology, 65: 39-61. http:// dx.doi.org/10.1002/ajp.20096.

POLLICK, A.S. \& DE WAAL, F.B.M. 2007. Ape gestures and language evolution. Proceedings of the National Academy of Sciences, 104: 8184-8189. http://dx.doi.org/10.1073/ pnas.0702624104.

PRADHAN, G.; ENGELHARDT, A.; VAN SCHAIK, C. \& MAESTRIPIERI, D. 2006. The evolution of female copulation calls in primates: a review and a new model. Behavioral Ecology Sociobiology, 59: 333-343. http://dx.doi.org/10.1007/s00265-0050075-y .

PREUSCHOFT, S. \& VAN HOOFF J.A.R.A.M. 1995. Homologizing primate facial displays: a critical review of methods. Folia Primatologica, 65: 121-137. http://dx.doi.org/10.1159/ 000156878 .

RAILS, K. 1971. Mammalian scent marking. Science, 171: 443449. http://dx.doi.org/10.1126/science.171.3970.443.

ROBERTS, A.I.; VICK, S.J. \& BUCHANAN-SMITH, H.M. 2012. Usage and comprehension of manual gestures in wild chimpanzees. Animal Behaviour. 84: 459-470. http://dx.doi.org/ 10.1016/j.anbehav.2012.05.022 .

ROBERTS, A.I.; VICK, S.J.; ROBERTS, S.G.B.; BUCHANANSMITH, H.M. \& ZUBERBÜHLER, K. 2012. Structure-based repertoire of manual gestures in wild chimpanzees: statistical analyses of a graded repertoire system. Evolution and Human Behavior, 33: 578-589. http://dx.doi.org/10.1016/ i.evolhumbehav.2012.05.006.

ROMERO, T.; CASTELLANOS, M.A.; DE WAAL, F.B.M. 2010. Consolation as possible expression of sympathetic concern among chimpanzees. Proceedings of the National Academy of Sciences, 107: 12110-12115. http://dx.doi.org/10.1073/ pnas.1006991107.

ROMERO, T.; CASTELLANOS, M.A.; DE WAAL, F.B.M. 2011. Post-conflict affiliation by chimpanzees with aggressors: other-oriented versus selfish political strategy. PloS One, 6: 22173. http://dx.doi.org/10.1371/journal.pone.0022173.

ROMERO, T.; DE WAAL, F.B.M. 2010. Chimpanzee (Pan troglodytes) consolation: Third party identity as a window on possible function. Journal of Comparative Psychology, 124: 278286. http://dx.doi.org/10.1037/a0019144.

ROWELL, T. E. 1972. Female reproductive cycles and social behavior in primates. Advances in the Study of Behavior, 4: 69105. http://dx.doi.org/10.1016/S0065-3454(08)60007-8 .

ROWELL, T.E. \& CHALMERS, N.R. 1970. Reproductive cycles of the mangabey Cercocebus albigena. Folia Primatologica, 12: 264-272. http://dx.doi.org/10.1159/000155296 .

ROWELL, T.E.; WILSON, C. \& CORDS, M. 1991. Reciprocity and partner preference in grooming of female blue monkeys. International Journal of Primatology, 12: 319-336. http:// dx.doi.org/10.1007/BF02547615.

RUKSTALIS, M.; FITE, J.E. \& FRENCH, J.A. 2003. Social change affects vocal structure in a callitrichid primate (Callithrix kuhlii). Ethology, 109: 327-340. http://dx.doi.org/10.1046/j.14390310.2003.00875.x

RYLANDS, A.B. 1982. The behaviour and ecology of three species of marmosets and tamarins (Callitrichidae, Primates) in Brazil. Thesis, University of Cambridge, Cambridge, UK. 314p.

SAMBROOK, T.D.; WHITEN, A. \& STRUM, S.C. 1995. Priority of access and grooming patterns of females in a large and a small group of Olive baboons. Animal Behaviour, 50: 16671682. http://dx.doi.org/10.1016/0003-3472(95)80020-4 .

SANTANA, S.E.; ALFARO, J.L. \& ALFARO, M.E. 2012. Adaptive evolution of facial colour patterns in Neotropical primates. Proceedings of the Royal Society B: Biological Sciences, 279: 2204-2211. http://dx.doi.org/10.1098/rspb.2011.2326 .

SETCHELL, J.M. \& DIXSON, A.F. 2001. Changes in secondary sexual adornments of male mandrills (Mandrillus sphinx) are associated with gain and loss of alpha status. Hormones and Behavior, 39: 177-184. http://dx.doi.org/10.1006/ hbeh.2000.1628

SETCHELL, J.M. \& WICKINGS, E.J. 2005. Dominance, Status Signals and Coloration in Male Mandrills (Mandrillus sphinx). Ethology, 111: 25-50. http://dx.doi.org/10.1111/j.1439$\underline{0310.2004 .01054 . x}$.

SETCHELL, J.M. 2005. Do Female Mandrills Prefer Brightly Colored Males? International Journal of Primatology, 26: 715735. http://dx.doi.org/10.1007/s10764-005-5305-7 .

SETCHELL, J.M.; VAGLIO, S.; MOGGI-CECCHI, J.; BOSCARO, F.; CALAMAI, L. \& KNAPP, L.A. 2010. Chemical composition of scent-gland secretions in an old world monkey (Mandrillus sphinx): influence of sex, male status, and individual identity. Chemical Senses, 35: 205-20. http://dx.doi.org/10.1093/ chemse/bjp105.

SEYFARTH, R.M. \& CHENEY, D.L. 2010. Production, usage, and comprehension in animal vocalizations. Brain and Language, 115: 92-100. http://dx.doi.org/10.1016/j.bandl.2009.10.003 .

SEYFARTH, R.M. 1977. A model of social grooming among adult female monkeys. Journal of Theoretical Biology, 65: 671-698. http://dx.doi.org/10.1016/0022-5193(77)90015-7 .

SEYFARTH, R.M. 1980. The distribution of grooming and related 
behaviours among adult female Vervet monkeys. Animal Behaviour, 28: 798-813. http://dx.doi.org/10.1016/S00033472(80)80140-0 .

SEYFARTH, R.M.; CHENEY, D.L.; BERGMAN, T.; FISCHER, J., ZUBERBÜHLER, K. \& HAMMERSCHMIDT, K. 2010. The central importance of information in studies of animal communication. Animal Behaviour, 80: 3-8. http://dx.doi.org/ 10.1016/j.anbehav.2010.04.012.

SICCHAR, L.A. \& HEYMANN, E.W. 1992. Preliminary observations on external signs of oestrus in moustached tamarins, Saguinus mystax, Callitrichidae. Laboratory Primate Newsletter, 31: 4-6.

SILK, J.B. 2002. The form and function of reconciliation in primates. Annual Review of Anthropology, 31: 21-44. http:// dx.doi.org/10.1146/annurev.anthro.31.032902.101743 .

SILVA, H.P.A. \& SOUSA, M.B.C. 1997. The pair-bond formation and its role in the stimulation of reproductive function in female common marmosets (Callithrix jacchus). International Journal of Primatology, 18: 387-400. http://dx.doi.org/10.1023/ A:1026386417039.

SLOCOMBE, K.E. \& ZUBERBUHLER, K. 2005a. Functionally referential communication in a chimpanzee. Current Biology, 15: 1779-1784. http://dx.doi.org/10.1016/j.cub.2005.08.068 .

SLOCOMBE, K.E. \& ZUBERBUHLER, K. 2005b. Agonistic screams in wild chimpanzees vary as a function of social role. Journal of Comparative Psychology, 119: 67-77. http://dx.doi.org/ 10.1037/0735-7036.119.1.67.

SMITH, T.E. \& ABBOTT, D.H. 1998. Behavioral discrimination between circumgenital odor from peri-ovulatory dominant and anovulatory female common marmosets (Callithrix jacchus). American Journal of Primatology, 46: 265-284. http://dx.doi.org/ $10.1002 /($ S ICI $) 1098-2345$ (1998)46:4<265::AID AJP1>3.3.CO;2-4 .

SMUTS, B.B. 1987. Sexual competition and mate choice. Pp. 385-399. In: B.B. Smuts, D.L. Cheney, R.M. Seyfarth, R.W. Wrangham \& T.T. Struhsaker (eds.). Primate societies. Chicago: The University of Chicago Press.

SNOWDON, C.T. \& SOINI, P. 1988 The tamarins, genus Saguinus. Pp. 223-298. In: R.A. Mittermeier, A.B. Rylands, A.F. CoimbraFilho \& G.A.B da Fonseca. Ecology and Behaviour of Neotropical Primates, Vol. 2, Washington, DC: World Wildlife Fund

SNOWDON, C.T.; TANNENBAUM, P.L.; SCHULTZDARKEN, N.J.; ZIEGLER, T.E.; FERRIS, C.F. 2011. Conditioned sexual arousal in a nonhuman primate. Hormones and Behavior, 59: 696-701. http://dx.doi.org/10.1016/ j.yhbeh.2010.10.009.

SNOWDON, C.T.; ZIEGLER, T.E.; SCHULTZ-DARKEN, N.J. \& FERRIS, C.F. 2006. Social odours, sexual arousal and pairbonding in primates. Philosophical Transactions of the Royal Society B: Biological Sciences, 361: 2079-2089. http://dx.doi.org/

\section{$\underline{10.1098 / \text { rstb. } 2006.1932}$}

SOUSA, M.B.C.; MOURA, S.L.M. \& MENEZES, A.A.L. Circadian variation with a diurnal bimodal profile on scent-marking behavior in captive common marmosets (Callitrhix jacchus). International Journal of Primatology, 27: 263-272. http:// dx.doi.org/10.1007/s10764-005-9009-9.

SOUSA, M.B.C.; SILVA, H.P.A.; ALBUQUERQUE, A.C.S.R.; TEIXEIRA, I.C.D.; RAULINO, F.C. \& OLIVEIRA, A.L. 1997. Resposta Reprodutiva de femeas de Callithrix jacchus a pareament os sucessivos: Repensando o "mate guarding" e o "pair-bond". Pp. 91-108. In: M.B.C. Sousa \& A.A.L. Menezes (eds.). A Primatologia no Brasil, Vol. 6.

STEVENSON, M.F \& POOLE, T.B. 1976. An ethogram of the common marmoset (Callithrix jacchus jacchus): General behavioural repertoire. Animal Behaviour, 24: 428-451. http:// dx.doi.org/10.1016/S0003-3472(76)80053-X.

TANAKA, I. \& TAKEFUSHI, H. 1993. Elimination of external parasites (lice) is the primary function of grooming in Free-ranging Japanese Macaques. Anthropological Science, 101: 187-193. http:/ /dx.doi.org/10.1537/ase.101.187.

TERRY, R.L. 1970. Primate grooming as a tension reduction mechanism. The Journal of Psychology, 76: 129-136. http:// dx.doi.org/10.1080/00223980.1970.9916830.

THIERRY, B. 1984. Clasping behaviour in Macaca tonkeana. Behaviour, 89: 1-28. http://dx.doi.org/10.1163/ 156853984X00010.

TINBERGEN, N. 1963. On aims and methods of ethology. Zeitschrift für Tierpsychologie, 20: 410-433. http://dx.doi.org/ 10.1111/j.1439-0310.1963.tb01161.x .

TOMASELLO, M. \& CALL, J. 1997. Primate cognition. New York: Oxford University Press.

TOMASELlO, M. \& CARPENTER, M. 2007. Shared intentionality. Developmental Science, 10: 121-125. http:// dx.doi.org/10.1111/j.1467-7687.2007.00573.x .

TUTIN, C.E.G. 1979. Responses of chimpanzees to copulation, with special reference to interference by immature individuals. Animal Behaviour, 27: 845-854. http://dx.doi.org/10.1016/00033472(79)90022-8 .

VAN HOOFF, J.A.R.A.M. 1967. The facial displays of the Catarrhine monkeys and apes. Pp. 7-68. In: D. Morris. Primate Ethology. Aldine. Chicago.

VAN HOOFF, J.A.R.A.M. 1972. A comparative approach to the phylogeny of laughter and smiling. Pp. 209-241. In: R. Hinde (ed.). Non-verbal Communication. Cambridge University Press. Cambridge.

VAN HOOFF, J.A.R.A.M. 1973. A structural analysis of the social behaviour of a semi-captive group of chimpanzees. Pp. 75162. In: M. von Cranach \& I. Vine. Expressive Movement and Nonverbal Communication. Academic Press. London. 
VANDENBURGH, J.G. 1965. Hormonal basis of sex skin in male rhesus monkeys. General and Comparative Endocrinology, 5: 31-34. http://dx.doi.org/10.1016/0016-6480(65)90065-1 .

VOROBYEV, M. \& OSORIO, D. 1998. Receptor noise as a determinant of colour thresholds. Philosophical Transactions of the Royal Society B: Biological Sciences, 265: 351-358. http:// dx.doi.org/10.1098/rspb.1998.0302 .

WAITT, C. \& BUCHANAN-SMITH, H.M. 2006. Perceptual considerations in the use of colored photographic and video stimuli to study nonhuman primate behavior. American Journal of Primatology, 68: 1054-1067. http://dx.doi.org/10.1002/ajp.20303.

WAITT, C.; LITTLE, A.C.; WOLFENSOHN, S.; HONESS, P.; BROWN, A.P.; BUCHANAN-SMITH, H.M.; PERRETT, D.I. 2003. Evidence from rhesus macaques suggests male coloration plays a role in female primate mate choice. Proceedings of the Royal Society, 270: 144-146. http://dx.doi.org/10.1098/ rsbl.2003.0065.

WALLER, B.M. \& DUNBAR, R.I.M. 2005. Differential behavioural effects of silent bared teeth display and relaxed open mouth display in chimpanzees (Pan troglodytes). Ethology, 111: 129-142. http://dx.doi.org/10.1111/j.1439-0310.2004.01045.x .

WHITE, B.C.; DEW, S.E.; PRATHER, J.R.; STEARN, S.M.; SCHNEIDER, E. \& TAYLOR, S. 2000. Chest-rubbing in captive woolly monkeys (Lagothrix lagotricha). Primates, 41: 185-188. http://dx.doi.org/10.1007/BF02557799 .

WHITEHEAD, J. M. 1995. Vox Alouattinae: a preliminary survey of the acoustic characteristics of long distance calls of howling monkeys. International Journal of Primatology, 16: 121-144. http:/ /dx.doi.org/10.1007/BF02700156.

WHITEHEAD, J.M. 1987. Vocally mediated reciprocity between neighbouring groups of mantled howling monkeys, Alouatta palliata palliata. Animal Behaviour, 35: 1615-1627. http:// dx.doi.org/10.1016/S0003-3472(87)80054-4 .

WINTER, M. 1977. Some aspects of the ontogeny of vocalizations of hand-reared common marmoset. Pp. 127-139. In: H. Rothe, H. J. Wolters \& J. P. Hearn (eds.) Biology and behaviour of marmosets. Proceedings of the marmoset workshop. Gottingen: Eigenverlag Rothe.

WRIGHT, P. C., IZARD, M. K. \& SIMONS, E. L. 1986. Reproductive cycles in Tarsius bancanus. American Journal of
Primatology, 11: 207-215. http://dx.doi.org/10.1002/ ajp. 1350110302 .

ZAHAVI, A. 1977. The cost of honesty (further remarks on the handicap principle). Journal of Theoretical Biology, 67: 603-605. http://dx.doi.org/10.1016/0022-5193(77)90061-3 .

ZAHAVI, A. 1991. On the definition of sexual selection, Fisher's model, and the evolution of waste and of signals in general. Animal Behaviour, 42: 501-503. http://dx.doi.org/10.1016/S00033472(05)80052-1.

ZELLER, U.; EPPLE, G.; KU“DERLING, I. \& KUHN, H.J. 1988. The anatomy of the circumgenital scent gland of Saguinus fuscicollis (Callitrichidae, Primates). Journal of Zoology, 214: 141156. http://dx.doi.org/10.1111/j.1469-7998.1988.tb04992.x .

ZIEGLER TE, WITTWER TE, SNOWDON CT. 1993b. Circulating and excreted hormones during the ovarian cycle in the cotton-top tamarin, Saguinus oedipus. American Journal of Primatology, 31: 55-65. http://dx.doi.org/10.1002/ ajp.1350310106 .

ZIEGLER, T.E.; EPPLE, G.; SNOWDON, C.T.; PORTER, T.A.; BELCHER, A.M. \& KUDERLING, I. 1993a. Detection of the chemical signals of ovulation in the cotton-top tamarin, Saguinus oedipus. Animal Behaviour, 45: 313-322. http://dx.doi.org/ $\underline{10.1006 / \text { anbe.1993.1036 }}$.

ZIEGLER, T.E.; JACORIS, S. \& SNOWDON, C.T. 2004. Sexual communication between breeding male and female cotton-top tamarins (Saguinus oedipus) and its relationship to infant care. American Journal of Primatology, 64: 57-69. http://dx.doi.org/ 10.1002/ajp.20061.

ZINNER, D.P.; NUNN, C.L.; VAN SCHAIK, C.P.; KAPPELER, P.M. 2004. Sexual selection and exaggerated sexual swellings of female primates. Pp. 71- 89. In: P. Kappeler \& C. van Schaik. Sexual selection in primates: New and comparative perspectives. Cambridge University Press, Cambridge, UK. http://dx.doi.org/ $\underline{10.1017 / \mathrm{CBO} 9780511542459.007}$.

ZUBERBUHLER, K. 2000a. Causal knowledge of predators' behaviour in wild Diana monkeys. Animal Behaviour, 59: 209220. http://dx.doi.org/10.1006/anbe.1999.1296.

ZUBERBUHLER, K. 2000b. Referential labelling in wild Diana monkeys. Animal Behaviour, 59: 917-927. http://dx.doi.org/ 10.1006/anbe.1999.1317. 